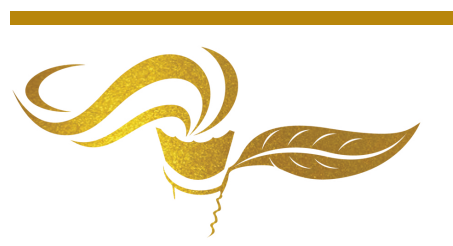

\title{
Cooperation of the Western Balkans States: Opportunity to Overcome Security Challenges
}

\author{
Bejtush Gashi ${ }^{1}$ and Gurakuç Kuçi ${ }^{2}$ \\ ${ }^{1}$ Dean at Faculty of Public Safety, KAPS Vushtrri, Republic of Kosovo, \\ email:bejtushg2002@yahoo.com \\ ${ }^{2} \mathrm{PhD}$. Cand. for International Relations and History of Diplomacy, University of Tetovo, \\ email:gurakuqkuqi@gmail.com
}

Received 22 May, 2020; Revised November 15, 2020; Accepted November 15, 2020

Available online November 15, 2020 at www.atlas-journal.org, doi: 10.22545/2020/00142

\begin{abstract}
- he Western Balkans is dominated by its geographical position, which, after the end of the Cold War in the 1990s, was one of the regions that experienced the most difficult transition because this process was accompanied by bilateral and multilateral conflicts, with local and regional wars, with political and ethnic clashes. As a consequence, it was also politically fragmented on its map. The international community actively intervened in the Balkans with various civilian and military missions, respectively during the conflict in Bosnia and Herzegovina, Kosovo and North Macedonia (former FYROM). These international interventions have yielded concrete results in the process of overall democratic reforms of the countries of the region, with particular emphasis on the security field, as well as the aspect of integration reforms in both NATO and the EU. Fragmentation of the Western Balkans came for many historical, political, economic, military, geopolitical and strategic reasons. This process also had consequences for the integration process of this region. But it is currently fully oriented towards European and Euro-Atlantic structures. No Balkan countries including Kosovo have any other orientations besides these (there are doubts about Serbia). Serbia has stated that it does not want NATO membership, while Russia has tried and is constantly trying to cause chaos in the Western Balkans. How this chaos is caused and how the cooperation of the countries of this region has affected and is influenced is the essence of our work that will draw conclusions about how to act in the future.
\end{abstract}

Keywords: Western Balkans, regional peace, theory of chaos, regional security, COVID19.

\section{Introduction}

The democratic processes of the 1990s in the Western Balkans, with particular emphasis after the fall of the Berlin Wall, were followed entirely by different challenges compared to those during the Cold War. This phase brought about major changes in the political and security scene, as the scenario of the German Union 
and the dissolution of the Soviet Union in 1991 was realized, which affected the course of many conflicts around the world, including many conflicts and the breakup of federal states in South Africa, in the Middle East, in some parts of Europe as well as conflicts in the Western Balkans (Gashi, Hidri, 2008, 2009, [1]).

The Western Balkans was one of the regions that experienced the most difficult transition, because this process was accompanied by bilateral and multilateral conflicts, local and regional wars, political and ethnic clashes. Consequently, the Balkans were politically fragmented on its map as well. Of the six main Balkans states that we had after World War II, which included Albania, Greece, Turkey, Yugoslavia, Bulgaria and Romania, after the Cold War we have a Balkans with new states such as Slovenia, Croatia, Bosnia and Herzegovina, Northern Macedonia, Montenegro and Kosovo. Fragmentation of the Balkans came for many historical, political, economic, military, geopolitical and strategic reasons. This process also had consequences for the integration process of this region. The international community has actively intervened in the Balkans, namely in the conflict period in Bosnia and Herzegovina, Kosovo and Northern Macedonia, the international presence being civilian and military. In these international engagements, the USA, NATO, the EU, the UN, the OSCE, the EC and a number of regional organization and non-political bodies have played a decisive role.

Actually, the Western Balkans is entirely oriented towards European and Euro-Atlantic structures. No Western Balkans country including Kosovo has any other orientations besides these. This makes the process easier because we are dealing with the acceptance of the same values and access to the same regional, European and global interests.

Regional cooperation, in order to create a new spirit and order through dialogue, cooperation and trust, should be the objective of the security institutions in the short and long term of the Western Balkans states. Basically this strategic vision is the recognition of the state of Kosovo by neighboring states and its return to a factor of security and stability in Southeast Europe. The Republic of Kosovo aims to be a factor of stability and peace in the region and does not express hostility and territorial claims for changing the boundaries with the use of force. Kosovo is against creating regional crises and conflicts and resolving them by means of violence. In this context, one of the strategic goals is to build the structure of the security system and to provide the capacity to develop peace support operations, in support of international law and humanitarian principles, under the guidance of the United Nations, NATO $^{1}$ and the European Union.

The strategic objective of Kosovo's security policy is to integrate into Euro-Atlantic security structures. The membership of Kosovo in NATO and EU is a primary and long-term objective, which has the full support of the people of Kosovo and the political spectrum. Kosovo does not rely on the security of the country simply on its own forces, but on joint efforts, integration and cooperation with international organizations.

An important factor in the security issue is the COVID19 pandemic. This pandemic, in addition to the negative influences on health, has also caused negative influences on the economy, politics and external influences. States seeking to extend their interests, or as it is otherwise called 'donation diplomacy', have used aid to extend their influence. A special part of this is devoted at the end to this kind of diplomacy and the way of dealing with it within the theme of the paper.

\section{Theoretical review of the cooperation of the Western Balkans countries}

The Western Balkans region (Kosovo, Albania, Northern Macedonia, Montenegro and Serbia) where you can find part of the peer-reviewed research on the two methodical approaches created from us. The first approach is widespread regional inland and the second approach will give us the mutual protection of the Western Balkans beyond and interaction the region, for example, Balkan countries with EU countries and vice versa. To elaborate on these two approaches we have taken five theories related to international

\footnotetext{
${ }^{1}$ NATO is considered / conceived as a community, where countries come together to provide collective defense and the maintenance of peace and security through the contributions that each member state provides for collective security and defense.
} 
relations and security policies that are: domino theory, prisoner dilemma, security theory, functionalist theory and chaos (Gerasimov's) theory. Within these two approaches and five theories we provide a historical and analytical treatment of events by drawing conclusions of the region's imposing cooperation which we explain at the end of the paper.

Domino Theory - The domino theory emerged during the 1950s and 1980s and was being used as a requirement by the USA government to justify its foreign policy actions. Domino theory was a subordinate to the Truman Doctrine, or rather Kenann's, where this doctrine foresaw the suppression of communism in every country in the world where it appeared.

It was Dwight Eisenhower, the USA President, who stated this theory during a conference on April 7, 1954, referring to the problems that were emerging in Indochina. At the conference he said: "Finally, you have broader considerations that might follow what you would call the "falling domino" principle. You have a row of dominoes set up, you knock over the first one, and what will happen to the last one is the certainty that it will go over very quickly. So you could have a beginning of a disintegration that would have the most profound influences (Eisenhower 2020, [2])".

Eisenhower warned that the collapse of a state in a particular region under communism meant that the whole region would be swept away by communism and states would begin to fall one by one under communism. He called this the "dominoes collapse" where then a collapse of states would be almost unstoppable as in Indochina. If Vietnam had fallen into communism, then the surrounding countries such as Laos, Cambodia and other surrounding countries were also in the queue.

Today the "effect of domino theory" has gone beyond the Cold War use and regional dimensions. Domino theory is now used in economics as Baldwin (Baldwin, 1993, [3]) argues and in many other fields, whether political, economic, social, ecological, etc. One effect of domino theory today can be traced back to the spread of viral diseases that the world faces from time to time, such as now with Coronavirus or earlier with Sars, Ebola, etc.

The effect of domino theory has also been applied during the 1990s in the Western Balkans by UN and NATO forces using preventive measures to escalate war from state to state, as in the case of Northern Macedonia or Albania, deployed peacekeeping forces under the UN mission. But that theory still holds true today in the Western Balkans in the field of security when it comes to regional co-operation in preventing vicious campaigns like Russia's "chaos theory" created by Russian General Gerasimov.

Prisoner Dilemma - is an example of a game theory similar to probability theory, where it shows the rationality of the parties' action in a scheme that can pull both winning parties or only one winning party, or all losers. Even this strategy was created during the Cold War of 1950 by Melvin Dresher and Albert Tucker. The theory says: Two members of a criminal gang are arrested and jailed. Each of the prisoners is in isolation and has no means of communicating with the other.

Prosecutors don't have enough evidence to convict the party on the main charge, but they have enough to convict both on a lesser charge. At the same time, prosecutors offer each prisoner a deal. Each prisoner is given the opportunity to either betray the other by proving that the other has committed the crime, or to cooperate with the other by remaining silent. The possible outcomes are:

- If A and B each betray the other, they each serve two years in prison;

- If A betrays B but B remains silent, A will be released and B will serve three years in prison (and vice versa);

- If A and B both remain silent, both will serve only one year in prison (on a lesser charge) (Nicholas, $2014,[4])$.

Indeed, this theory shows that treachery test rationality of the realpolitik style where it shows that the parties are in fact more likely to betray, but in another version the prisoner's dilemma pushed states into solidarity for two reasons: since they can have the same fate in another case where they will be betrayed and have the bad image of a traitor in a world where the image of a country is the most important element and in the second case the betrayed country will seek revenge and he will do this without choosing the means 
or becoming an ally with the enemies of the traitor. In this case, we have to move towards co-operation in order to achieve faster the states towards the promotion and elimination of waste and revenge. So betrayal is a zero-sum game.

Theory of Security - or International Security has been put into prominent studies shortly after World War II, but as an area it is not new as security issues and is old as history itself.

Kolodziej compared international security with the Tower of Babel (Kolodziej, 2005, 11, [5]), so as a space the higher you try to get, the more it is destroyed and changed. Walter Lippman viewed security as a country's ability to safeguard its core values, while David Baldwin emphasized that pursuing security sometimes requires sacrificing some values (Ullman, 1983, [6]). Barry Buzan views security as a study of international security rather than just a threat study, but also as a study of threats that require immediate action and that security is something between peace and power (Croft, Terriff, 2000, [7]). So, the theory of security being completely uncertain in the future requires the cooperation and sacrifice of some values which can make a future safer.

Today the security sphere extends not only to the classical military, but also to terrorism, ecology and the political, social and economic spheres. In states and regions that are powerless to face such challenges alone, then cooperation is an inevitable means of ensuring the existence, development and integration of something as a matter of peace and power, as something between progress and sovereignty or as something between anger and good or something between history and the future. Functionalist theory - Functionalism is a theory of regional and global international integration and as such it developed mainly during the Cold War era but its origin can also be traced to Immanuel Kant or early.

This theory of integration is based on classical alliances, alliances that comprise regional and international organizations such as the European Union, NATO, UN, IMF, NAFTA, OPEC, etc. Functionalism proposes to build a form of authority based on functions and requirement, which link authority with requirements, scientific knowledge, etc., thus providing a supranational concept of authority. This approach rejects realization in interpreting the proliferation of international organizations (Wolf, 1973, [8]).

Functionalism has also changed over time and has become a more regional approach and has been termed neofunctionalism, as a more pragmatic method of making supraterritorial, supranational initiatives or international governmental and non-governmental organizations operational. This approach offers the space and opportunity that cooperation is a need in the world of interdependence and as such drives states to necessarily cooperate because of needs in different spheres.

Doctrine of Chaos (Gerasimov's Doctrine) - In February 2013, Russia's Chief of General Staff, Valery Gerasimov, developed a hybrid theory in a published article.

According to Molly McKew in that document, "the value of science is foresight". Gerasimov took the tactics developed by the Soviets by mixing them with strategic military thinking for total war, and put forward a new theory of modern warfare, one that looks more like revenge on enemy society than an attack on the leader (Mckew, Glorioso, 2020, [9]).

Explaining Gerasimov's doctrine, Zev Shalev says that doctrine foreshadows a "hybrid war" where information and protests are more effective weaponry than tanks and nuclear weapons or tanks. "Nonmilitary means to achieve political and strategic goals ... have outstripped the power of the weapons force in their effectiveness." In other words, use propaganda and protests to polarize a population and plant chaos behind enemy lines (Shalev, 2017, [10]).

We have seen this theory in practice in the Western Balkans in Serbia through Sputnik, Montenegro and Macedonia through the tendency for coups and in other countries with direct or indirect interference with different funding.

\section{The Two Histories of Intra-Balkan and Outside-Balkan Cooperation}

The first approach: intra-Balkan cooperation from 1912 
The history of Balkan cooperation doesn't have a good track record, namely the cooperation of the Balkan countries is in fact alliances of war for the persecution of an invader, the seizure of lands of any people or the creation of circumstances for the existence of kingdoms or federations. The Western Balkans had been a space occupied and ruled by the Ottoman Empire excluding the present-days Croatia and Slovenia. But even under this empire, this region differed in its rule as regions such as the Servian/Serbian, Bulgarian or Greek kingdoms had wide autonomy, while the Albanian lands were under pure Ottoman rule.

The First Balkan War had united the Balkan Slavs in the fight against the Ottoman Empire in October 1912. Serbia, Montenegro, Greece and Bulgaria had an alliance with each, and even a guarantor of the alliance between Serbia and Bulgaria was Russia. This agreement also provided for the division of territories after the war.

An invasion of Albania with the intention of Serbia's exit into the Adriatic Sea was seen as a danger to Serbia's domination of the Adriatic, and Serbia's bases were also conceived as Russian bases by the then Austro-Hungarian and Italian diplomats (Hall, 2000, 54, [11]). Particular attention to the agreement between Greece and Serbia was the disregard of Albanian existence as a political entity. The agreement stipulated that the borders of Serbia and Greece would meet on the Shkumbin River, which separates northern Albania from the south. (Ion, 1918, [12]).

According to this two-part treaty (a secret part) Serbia gained after the war the Albanian territories north of the Shkumbin River, while Greece to the south of it, while Montenegro agreed with Serbia to keep Shkodra, Peja, Deçani and Gjakova under its occupation. (Bytyçi, 2012, 28, [13]).

One such idea was brought to light in 1992 during Slobodan Milosevic's visit to the Greek Riviera that had begun on June 26th (Ajvazi, 2009, [14]). He had even gone further when he publicly proposed a confederation between Greece, Macedonia and Serbia (Reuters, 1992, [15]). Such an idea had received support, and this idea was most liked by some politicians in Macedonia (Liqui Search).

Cooperation in the Western Balkans was also attempted by the second Yugoslavia under the leadership of Josip Broz-Tito. An agreement for a Balkan confederacy had also been reached by 1941 between the Kingdom of Yugoslavia (Serbia, Croatia and Slovenia) and Greece with the mediation of Great Britain, but with the intention of uniting Bulgaria and Romania as well (History Commons).

Even a feasible project of work was the project of the "Balkan Federation" that would include Yugoslavia, Bulgaria and Albania. (Buxhovi) However, Tito wanted hegemony in the region, including Albania, and to fix the historical problem of Macedonia where he wanted to unify the entire territory of Macedonia from Vardar, then with Pireun of Macedonia in Bulgaria, with the exit of Macedonia to the Aegean to Greece, and thus creating a large federation that would include Bulgaria and Greece (Perovic, 2007, [16]), as Albania was already economically and culturally integrated within Yugoslavia under an agreement (Buxhovi).

These plans would spur Stalin's demise with Tito, and Russia wouldn't allow such actions as it would disrupt the geostrategic balances established after World War II but also allow competition within the communist bloc. Arben Xhaferi said today's Macedonia exists because of its role as a buffer zone, which prevents friction between Balkan states (Robelli, 2011, 139, [17]).

All this cooperation would change radically after the beginning of the destruction of Yugoslavia, the start of the war in Bosnia and Herzegovina, and the Christmas Ultimatum by George H. W. Bush in 1992.

Second Approach: Outside Cooperation for the Balkans "Preventive Diplomacy"

The coming to power of Slobodan Milosevic in Serbia and the beginning of the destruction of Yugoslavia due to Serbian megalo-ideas for the creation of a Greater Serbia and the disappearance of Albanians based on the memorandum of the Serbian academy SUNA, created new circumstances not only for the region but also for the international community.

These events immediately after the Cold War and during the Gulf War crisis, where Iraq had invaded Kuwait, and the US-led international community was preparing to intervene there were intentions for Milosevic to surprise the international community for invasion of communist Yugoslavia under the nationalchauvinist Greater Serbia.

Moreover, when the change of administration in the USA in late 1992 from the old Bush to Bill Clinton 
was taking place, Serbia had taken action in the Albanian search for weapons, enabling the creation of an occupied and surrendered territory that under international law would be known as a fait accompli.

But Bush hadn't fallen prey to this tactic and sent a letter to Milosevic on December 25, 1992, stating: "In the event of a conflict in Kosovo caused by Serbian actions, the United States have prepared 50,000 troops to intervene with its military forces against Serbs in Kosovo and Serbia" (The New York Times, 1999, [18]). The same was repeated on February 13, 1993 by Secretary of State, Warren Christopher, who said: "We remain prepared to respond to the Serbs in the event of a conflict in Kosovo caused by Serbia's actions" (The New York Times, 1999, [18]).

After these events, then began the development of the second approach to the Western Balkans, the Carrington Conference which was about solving the problem of Yugoslavia, also known as the International Conference on the Former Yugoslavia where Kosovo wasn't part of it.

In Kosovo, Sandzak and Vojvodina would be a mission of the Security and Cooperation Council in Europe (CSCE later OSCE). Then came the London Conference, which was to be held on August 26-27, 1992, where Kosovo was still not part of the conference. After all these events then more than ever the EU, US, NATO, CSCE/OSCE and the UN would be involved in the Western Balkans.

The new of all this external engagement under the second approach in the Western Balkans was with the beginnings of "preventive diplomacy". This was a new doctrine that we could draw in parallel with Truman's old doctrine of curbing communism, but that was about curbing Milosevic to pass the conflict in Macedonia and potentially Albania.

This kind of diplomacy began when some former Yugoslav countries signed a ceasefire and a UN mission was established with UNPROFOR peacekeeping purposes under Resolution 743 of 21 February 1992 (UN S/RES/743, 1992), which would then extend to Bosnia and Herzegovina. Whereas, by Resolution 795 of December 11, UNPROFOR required that it extend its authority and forces to the territory of Macedonia and have full coordination with the OSCE mission operating there (UN S/RES/795, 199, [19]).

The introduction of UN peacekeeping forces in Macedonia has been seen as a success of "preventive diplomacy". Such a mission was undertaken for the first time in the world in Macedonia, and its success in Macedonia in stopping any inter-ethnic crisis or conflict showed that potentially such actions were taken earlier in other countries of the former Yugoslavia, wars could be prevented (Cvetkovska, 1999, [20]).

This commitment would prevent the escalation of the war in Macedonia, but an external commitment to the Balkans to resolve the Bosnian issue couldn't be made until 1995 after the Dayton agreement, after a long war, thousands of victims, the Srebrenica massacre and NATO bombing for fifteen days over Serbian military targets.

After this turn came to Kosovo, Milosevic would have hoped that after Bosnia and the concessions there he could invade and cleanse Kosovo based on the "Horseshoe" plan. However, the international community, especially the West, didn't allow this to happen and after many negotiations led by Cristofer Hill, then Richard Holbrook, and negotiations in Rambouillet, it would be the turn of the NATO bombing of Serbian military targets in Kosovo and Serbia, which would end with the capitulation of Milosevic and the withdrawal of Serbian forces from Kosovo.

\section{The Two Approaches Incorporated for Stability and Peace in the Western Balkans}

With the end of the Kosovo War, a new phase was beginning for the entire Western Balkans, a phase where cooperation within the region and abroad would be primary to maintaining peace in the region and beyond. Many governmental and non-governmental organizations were involved in the process, including the EU, USA and UN with key roles both through UNMIK, KFOR, EULEX missions and through direct actions.

The EU would also begin to create space for EU membership and aspirations for the Western Balkan countries, as the stabilization process was long and painful. Kosovo was under the management of a foreign mission until independence, while other countries were all strained by the post-Yugoslav processes and wars, including Albania. 
However, countries in the region did not have many options for accessing each other internally and externally because:

- The Western Balkan countries couldn't cross each other for cooperation with other neighbors as they were confined to countries that were already or would soon become part of the European Union and NATO.

- The Western Balkan countries also had no better option than cooperating overseas with the EU, US and NATO while options such as Russia were irrelevant because the country itself was already in economic turmoil.

- The remaining option of approaching the West was that the latter required first stabilization and integration of the region internally with external assistance to continue integration with the outside.

This process of EU integration of the Western Balkans would begin in 2003, during the European Council meeting in Thessaloniki, the decision was made to open the European Union Programs to countries outside the EU and the EEA, which were in the process of Stabilization and Association. The aim of the participation of candidate countries and potential candidates in EU programs is to support their EU accession, to make them familiar with EU methods and policies and to strengthen cooperation between countries in different fields: research and innovation, education, culture, health, environmental protection, customs and taxation, justice, etc.

This process required the region to have internal stability and cooperation as the EU refuses to import the region's problems within it. On the other hand, NATO was also involved in peacekeeping with its military mission in Kosovo called KFOR and cooperative missions and agreements with countries such as Albania and Macedonia.

The region would remain stable and continue to do so even when Montenegro in 2006 and Kosovo in 2008 declared their independence, because external oversight of stability was overwhelming and from the inside there was no significant interest to be undermined, only Serbia was opposed to peace and to these two declarations of independence. That functionalism and security were crucial before the other ends of the war would also prove the recognition of Kosovo by its two neighbors, Macedonia and Montenegro.

The Western Balkans has been traveling through this integration process without Slovenia since 1 May 2004, which had joined the EU and later without Croatia, which would join on 1 July 2013. The Western Balkans were also integrating in the economic sphere, first with the Stability Pact for South Eastern Europe, and with 2006 the extension of the CEFTA agreement (Central European Free Trade Agreement).

But in the whole process there was no particular security cooperation between the Western Balkan countries, and where it was done only through NATO.

\section{New Global Spheres and Western Balkans Cooperation as Security}

Post-Cold War ideals for the end of history never came to fruition, but American hegemony as an unchallenged power had begun to fall, especially after the 2003 invasion of Iraq, the latter would continue to lead as a major but not contested superpower, because nuclear weapons, the revival of civilizations, the emergence of new powers, and the creation of new spheres of interest all constituted a balance of powers.

In 2005 Russian President Vladimir Putin had declared that USSR's breakup was a mistake (Putin, 2005, [21]). Whereas, following Kosovo's declaration of independence on February 17, 2008, in response to the West and especially the United States, Putin would intervene to break up Georgia's two provinces, South Ossetia and Abkhazia. On the other hand, Turkey had begun to show signs of leaving the West after many rejections by the EU, now Turkey had its own geo-strategy divided by the West devised by Ahmet Davutoglu implemented by Erdogan. The economic challenge of 2008 that had overwhelmed the world and the threats of terrorism, all these exits and polarizations of the world, would in fact for the 
Western Balkans be the impetus for deeper integration within it and wider cooperation abroad, with EU and NATO.

Russia in the Western Balkans, through Gerasimov's strategy of causing chaos, had seriously begun to undermine integration into the EU and NATO, but also towards peace in the region through its interventions as in the case of Montenegro, where it had sought It was a coup d'etat in the case of Macedonia as well, but various reports testify to influence in countries such as Albania and Kosovo and declaratively in Serbia.

\section{COVID19 Pandemic and Donation Diplomacy: Influence in the Western Balkans}

With the onset of crises, both benefactors and beneficiaries usually appear, and sometimes benefactors take advantage of the opportunity. The emergence of COVID19 pandemics was not at all a factor in the states abandoning their raison d'etat style interests. It's just that this crisis has led many countries to use coronavirus to help extend their geopolitical interests. The Chinese government had provided assistance to 82 countries in the fight against coronavirus, and had even come to Italy's aid before the EU. (news.cgtn.com, 2020)

The lack of EU assistance had provoked so many reactions in Italy that in April a survey found that $49 \%$ of citizens were in favor of Italy leaving the European Union (Gotev, 2020, [22]). The EU's response was almost immediate after the poll, in which, in addition to aid, they publicly apologized to Italy (Deutsche Welle , 2020, [23]). China's aid has also been dubbed "Donation Diplomacy (Wong 2020,' [24])". China has also helped the Western Balkans with aid in the fight against coronavirus, such as in Albania, Serbia and other countries, but not in Kosovo. While Turkey has helped all the countries of the Western Balkans, which has been done by both the US and the EU.

Russia, too, has taken a step beyond China and Turkey to strengthen its influence in the Balkans, especially with Serbia. It is worth noting the form of Moscow's assistance to Serbia, which was made through the control of the army, and the Russian soldiers carried out the operations together with the Serbian soldiers. The opportunity has not gone away for these soldiers to remain in Serbia even after the pandemic on the so-called "united front" against new challenges (Goble, 2020, [25]). The Kremlin seems committed to supporting its perceived success, hoping it can further increase Russian power in Belgrade and the Balkans against not only the West but also China (Goble, 2020, [25]). This attitude of the Russian army, even after the pandemic and their approach, is happening at a time when the United States is insisting on a final agreement between Kosovo and Serbia.

The diplomacy and ability of the three non-Western countries to intervene in times of crisis is great. Such crises in small and incapable countries can easily be overcome by the influence of neo-imperialist powers and even terrorist groups without the help of any superpower. To stop this, Kissinger says the United States should take post-pandemic measures based on the Marshall Plan and the Manhattan Project, which creates a global resistance to infectious diseases, heal economic wounds and protect the principles of the global liberal order, adding that the democracies in the world must defend and preserve their Enlightenment values (Kissinger, 2020, [26]).

The Western Balkans should be unique and to maintain its order it should become part of projects by the USA and the EU, because these projects will not come for specific countries but as a general measure, a cooperative approach of the region will to facilitate the exit from the economic crisis and the preparation in the future that in such cases the measures will be more effective in terms of health and economy.

\section{Conclusions According to Theories}

Domino theory - this theory in the case of the Western Balkans warns that the wrong moves of each country can lead to uncontrolled events with effects outside the region that would in turn lead to the potential disappearance of states like Kosovo, North Macedonia or Montenegro. As such, the domino theory in 
this case teaches us about the inevitability of the region's cooperation towards preserving itself first and secondly peace in the region and beyond. Any movement or collapse of one would mean breaking down a complicated historical and political system.

Prisoner's Dilemma - this theoretical example guides us that the cooperation of the Western Balkan countries is destined to be mandatory because every other variant sends us back to bloody history but also to total destruction of uncontrollable proportions. Also, this theory convinces us that any form of action of the countries of this region based on the principles of raison d'etat which affect the biting, destroying or damaging the other party, in fact has the domino and revenge effect that brings the game to points with many zeros.

Theory of Security- instructs the region that in order to preserve its existence, its values, its space, its state systems and continuity, it must find the form of internal cooperation and external secure support that doesn't require the disappearance of core values but only a necessary evolution as Baldwin points out. This form of functioning of the region, from the region's requirements for external support, then turns into a support that both sides need each other as in the case NATO-Western Balkans, when the latter had the need for NATO at the next stage and cooperation is deepening and security is not only stability but also peace and progress.

Functionalist Theory as Integration - this theory placing its importance on the integration of states and peoples, and especially its neo-functionalist version, in a world heading for multi-polarity, is essential to the ranking of the region. The region is inevitably of one-time importance and cannot be divided because in a small region with many great powers functionalist peace doesn't exist. Thus, neo-functionalism, seeking pragmatism, instructs us to pursue integration as a goal of peoples towards freedom and progress. Neo-functionalism makes it easier for the Western Balkans to integrate internally and externally into the EU and NATO.

Doctrine of Chaos (Gerasimov's Doctrine) - this doctrine originated by the Russian general and attempting to create irregularities in the Balkans, is a prophetic teaching of the region how cooperation and support with Russia doesn't bring freedom, progress and democracy, but corruption, oligarchy and autocracy. Among other things, the intentions of this doctrine are, in fact, to create chaos and disruption of order created by the West, which beyond the reach of influence is chaos and bloodshed. States aim for influence but when the influence shifts to chaos it leads to wars and genocides.

\subsection{Practical Conclusions}

The debate during the paper also includes conclusions and recommendations, but to facilitate the understanding of the paper we will summarize in some points the explanation of the paper, the inevitability of the region's actions and the importance of the practice.

- The Western Balkans region, due to its borders on the one hand with EU member states and geography as a peninsula, constitutes an inevitable regional cooperation. From land borders, the region finds it almost impossible to play real political neighborly policies with countries that are part of the EU, and examples of Peninsula and Islands show that co-operation solutions outside geographical constraints are compelling, especially when in the Western Balkans region that the other restriction is with EU countries.

- The EU doesn't carry within itself the Balkanization problems of the region, doesn't accept separate countries within itself to avoid a veto vote on the Balkan countries and disunity, and also doesn't accept countries that aren't integrated with each other and this imposes inevitable co-operation on the Western Balkans.

- The small geographical area of the Western Balkans makes its stability impossible by having states that belong to different global polarizations and if such a thing exists peace, security and stability become impossible, therefore the unity of the region towards the EU and NATO remains the opportunity to integrate and preserve values without alienating but evolving. 
- Looking at the history and the aftermath of the breakup of Yugoslavia makes it essential to preserve the current political structure of the region and integrate it only towards the prospect of preserving this form of sharing and cooperation that is guaranteed only by NATO, the EU and the USA.

- Small geographic space and large historical divisions are the two problems that need to be incorporated to bring development back to the region because in a world economy where large companies require large markets, none of them will invest in the single market, a regional country but as a whole the opportunities are real, as well as in a tense and divisive region where uncertainty is high the economy and investments remain far away from demand and this only enables destabilization and even depletion of the region.

- Theories that are part of our research and practices teach us in the last case with pandemic COVID19, that we must cooperate and create a more cooperative and responsive approach not only to pandemic crises, but also to natural disasters and risk issues. The current single approach reduces the capacity of each country to deal with any threat, and as such, exit from threat control has domino effects.

Funding: This research received no external funding.

Conflicts of Interest: The authors declares no conflict of interest.

\section{References}

[1] Gashi, B, P. Hidri. 2008. Konfliktet Ndërkombëtare Dhe Ndëëretnike, 209. Prishtinë, Kosoëë: Instituti për Studime tëë Sigurisëdhe Integrimeve.

[2] Eisenhower, D. n.d. "Foreign Relations of the United States, 1952-1954, Indochina, Volume XIII, Part 1." U.S. Department of State. U.S. Department of State. Accessed March $10,2020$. https://history.state.gov/historicaldocuments/frus1952-54v13p1/d716.

[3] Baldwin, R. (1993). A Domino Theory of Regionalism. National Bureau of Economic Research, no. w4465 (September 1993). https://doi.org/10.3386/w4465.

[4] Nicholas, M. (2014). The Basics of Game Theory and Associated Games. https://www.slideshare.net/ johnsonnick895/game-theory-paper-26049795, accessed November 8, 2020.

[5] Kolodziej, E.A., (2005). Security as a Tower of Babel. Security and international relations. pp.11 Cambridge University Press.

[6] Ullman, R. H. (1983). Redefining security. International security, 8, no. 1, pp. 129-153.

[7] Croft, S. and T. Terriff, eds. (2000). Critical reflections on security and change. Psychology Press.

[8] Wolf, P. (1973). International organization and attitude change: a re-examination of the functionalist approach. International Organization, 27, no. 3, pp. 347-371.

[9] Mckew, M K., and A. Glorioso. The Gerasimov Doctrine. POLITICO Magazine. Accessed March 5, 2020. https://www.politico.com/magazine/story/2017/09/05/gerasimov-doctrine-russia-foreign-policy-215538.

[10] Shalev, Z. Chaos Theory. Narativ, August 14, 2017. https://narativ.org/2017/08/14/chaos-theory/.

[11] Hall, R. (2000). First Balkan War Western Theater. The Balkan Wars 1912-1913. (p. 54). London, United Kingdom: Routledge.

[12] Diplomatic Documents, 1913-1917, Issued by the Greek Government Concerning the Greco-Serbian Treaty of Alliance and the Germano-Bulgarian Invasion in Macedonia: Part First. (1918). Diplomatic Documents, 1913-1917, Issued by the Greek Government Concerning the Greco-Serbian Treaty of Alliance and the GermanoBulgarian Invasion in Macedonia: Part First. The American Journal of International Law, 12(2), 86-139. http://doi.org/10.2307/2213276

[13] Bytyçi, E. (2012). Diplomacia imponuese e NATO-s në Kosovë. Tiranë, Shqipëri: Instituti i Studimeve të Europës Juglindore.

[14] Ajvazi, F. (2009, December 7). Okupimi, aneksimi dhe tentimi për serbizimin e Kosovës: 1912 - 1999. Mars 10, 2016, http://www.gazetakritika.net/Forumi/?itemid=2400 
[15] Reuters, News. (1992). Serbia Calls for Confederation with Greece. Serbia Calls for Confederation with Greece. Serbia Hellas. March 19, 2020. http://www.serbia-hellas.com/articles/confederation.html.

[16] Perovic, J. (2007). The Tito-Stalin Split: A Reassessment in Light of New Evidence. Journal of Cold War Studies, 9(2), 32-63. March 21, 2016. ërkim të kuptimit. Prishtinë, Kosovë: Koha.

[17] Robelli, E. (2011). Arbën Xhaferi rrëfen Në Tetovë në kërkim të kuptimit. Prishtinë, Kosovë: Koha.

[18] The New York Times. (1999, April 18). Crisis in the Balkans; Statements of United States' policy on Kosovo. April 9, 2016, http://www.nytimes.com/1999/04/18/world/crisis-in-the-balkans-statements-of-[6] -states-policy-on-kosovo.html

[19] UN. (n.d.). UN Security Council 3147th Meeting Resolution S/RES/795 December 11, 1992. April 9, 2016, http://www.nato.int/ifor/un/u921211a.htm

[20] Cvetkovska, B. V. (1999). Between Preventive Diplomacy and Conflict Resolution: The Macedonian Perspective of the Kosovo Crisis. Balkan Peace Study Center,40. April 8, 2016, http://www.makedonika.org/whatsnew/The Macedonian Perspective of the Kosovo Crisis.pdf

[21] Putin, V. 2005. Annual Address to the Federal Assembly of the Russian Federation. President of Russia. April 25, 2005. http://en.kremlin.ru/events/president/transcripts/22931.

[22] Gotev, G. (2020, April 18). Will Italy's coronavirus epidemic fuel the far right? May 4, 2020, https://www.euractiv.com/section/future-eu/news/will-italys-coronavirus-epidemic-fuel-the-far-right/

[23] Deutsche Welle. (2020, April 16). Coronavirus: EU apologizes to Italy for initial response: DW: 16.04.2020. May 4, 2020, https://www.dw.com/en/coronavirus-eu-apologizes-to-italy-for-initial-response/a-53142603

[24] Wong, E., \& Mozur, P. (2020, April 14). China's 'Donation Diplomacy' Raises Tensions With U.S. The New York Times. https://www.nytimes.com/2020/04/14/us/politics/coronavirus-china-trump-donation.html.

[25] Goble, P. (2020, April 14). Moscow Using Pandemic to Shore Up Alliance With Serbia Against NATO and China. Jamestown. https://jamestown.org/program/moscow-usingpandemic-to-shore-up-alliance-with-serbia-against-nato-and-china/?fbclid=IwAR0-9MK_khoiKvrOgrj5gKr_NvMfA4HC584NkNYW39LuW8yasWtGY3QMYU.

[26] Kissinger, H. (2020, April 3). The Coronavirus Pandemic Will Forever Alter the World Order. The Wall Street Journal. https://www.wsj.com/articles/the-coronavirus-pandemic-will-forever-alter-the-world-order11585953005 .

\section{Bibliography}

1. Buxhovi, Jusuf. Kosova 1945-1999. Prishtinë, Kosovë: Faik Konica.

2. China announces to help 82 countries fight COVID-19. (2020, March 21). May 4, 2020, https://news.cgtn. com/news/2020-03-20/China-announces-to-help-82-countries-fight-COVID-19-P1hcQcQKe4/index.html

3. Context of '1945: Yugoslav-Albanian Federation to Precede Inclusion of Bulgaria' http://www.historycom mons.org/context.jsp?item=kosovar_self-determination_tmln_91

4. Greece-Serbia Relations - Confederation Plan From 1992. (n.d.). Marrë Mars 10, 2016, http://www. liquisearch.com/greece-serbia_relations/confederation_plan_from_1992

5. Serbia calls for confederation with Greece. (1992, July 4). March 10, 2016, http://www.serbiahellas.com/articles/confederation.html

6. UN. (n.d.). UN Security Council 3055th Meeting Resolution S/RES/743 February 21, 1992. April 9, 2016, http://www.nato.int/ifor/un/u920221a.htm

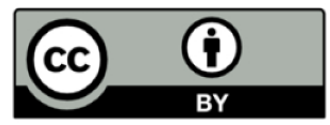

Copyright (C)2019 by the authors. This is an open access article distributed under the Creative Commons Attribution License (https://creativecommons.org/licenses/by/4.0/), which permits unrestricted use, distribution, and reproduction in any medium, provided the original work is properly cited. 


\section{About the Authors}

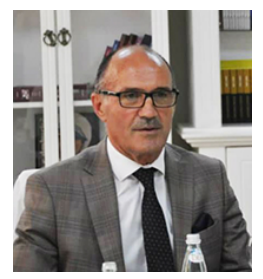

Prof. Assoc. Dr. Bejtush Gashi is the Dean of the Faculty of Public Safety and Professor of Security, Emergency and Terrorism subjects. Gashi has been Minister of Internal Affairs (2018) and Deputy Minister in the Ministry of Security Forces (2011-2014) in the Republic of Kosovo. He completed his basic studies at the University of Belgrade (1976 / 77-1983 / 83), his master's degree at the University of Zagreb (1985 / 86-1988 / 89) and his doctoral studies at the Defense Academy "Spiro Moisiu" in Tirana (2002 / 03-2005). Gashi has also taught courses at several Universities in Albania and Northern Macedonia. Prof. Assoc. Dr. Bejtush Gashi is the co-author of four university books such as: "Crisis Management System" (2012), "The Role and Responsibilities of the Police in the Internal Security System in Kosovo" (20012), "International and Interethnic Conflicts" (2008) and "The Yugoslav Army and its presence in Kosovo in the period 1945-1990" (2006).

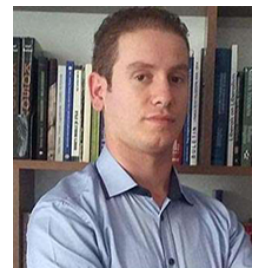

Mr.Sc. Gurakuç Kuçi is a PhD candidate in "International Relations and History of Diplomacy" at the University of Tetova and this year (2020) is expected to doctorate. He completed his basic studies in two faculties, respectively in two departments, in Political Science and Journalism at the University of Pristina "Hasan Pristina" and completed a master's degree in International Politics at the same university. Kuçi is the director of the Independent Institute for Political and Media Studies and has also worked in the field of journalism. Also, Mr. Kuçi provides ongoing media analysis on political issues. 